\title{
COMMON SENSE OR UNNECESSARY Complexity? The Recent Change to THE Right TO SiLENCE IN NEW SOUTH WALES
}

\section{Ashley Cameron*}

The New South Wales government has now enacted section 89A of the Evidence Act 1995 (NSW), which will significantly amend the right to silence. The new provision allows courts in certain circumstances to draw unfavourable inferences from evidence of silence in criminal proceedings. Parliament has justified the legislation as a 'common sense' approach, intended to prevent offenders hiding behind a wall of silence. However the benefits of the legislation are expected to be minimal at best. Although critics have already put forward weighty theoretical arguments opposing the enactment of the new provision, how it will operate in New South Wales courts remains to be seen. This article will undertake a detailed comparative analysis, examining the operation of similar legislation in the United Kingdom to determine how section 89A might be interpreted and applied in New South Wales. This analysis suggests that the need for extensive and complicated jury directions, the problems in determining whether the provision is to be invoked at all, and the complex test used in deciding whether it was reasonable for the accused to remain silent, will create significant difficulties in the application of section 89A. It is contended that the number and seriousness of these difficulties, coupled with the only limited benefit (if any) to be derived from the section, justify the close monitoring of section $89 A$ and its review at an appropriate time.

\section{INTRODUCTION}

The New South Wales Parliament has recently enacted section 89A of the Evidence Act 1995 (NSW), significantly altering the statutory pre-trial right to

\footnotetext{
* BEcon, LLB(Hons); Solicitor of the Supreme Court of New South Wales; Tipstaff in the Supreme Court of New South Wales.
} 
silence. ${ }^{1}$ Previously, a fundamental common law rule applied, according to which those who believed on reasonable grounds that they were suspected of a criminal offence were entitled to remain silent when questioned by officials; ${ }^{2}$ no unfavourable inferences could be drawn against them because of their silence. ${ }^{3}$ Indeed, as stated by the High Court in Petty $v$ The Queen, 'to draw such an adverse inference would be to erode the right of silence or to render it valueless'. ${ }^{4}$ The rule is reflected, although more narrowly, ${ }^{5}$ in section 89 of the Evidence Act 1995 (NSW), which prevents unfavourable inferences being drawn from a failure to answer questions or respond to representations of an investigating official. ${ }^{6}$ It should be noted that the common law remains applicable 'except so far as [the Evidence] Act provides otherwise expressly or by necessary intendment' ${ }^{7}$ Thus, to the extent to which the common law is not expressly or impliedly contradicted, the common law will continue to apply. However, in line with recent trends which seek to narrow the right to silence, ${ }^{8}$ the new legislation now allows the court, in some circumstances, to draw unfavourable inferences from evidence that accused persons, when questioned by police, failed to mention facts which they later relied upon at trial. ${ }^{9}$ Thus, in the words of the High Court, the previously applicable common law right to silence has been eroded or rendered valueless in these cases. ${ }^{10}$ Although the right to silence existing immediately prior to the recent enactment was not absolute, section 89A is a substantial and controversial amendment to the law, which is arguably unjustified.

It is contended that section $89 \mathrm{~A}$ causes such significant problems in its operation that its enactment may be unwarranted. Although critics ${ }^{11}$ have so far

\footnotetext{
${ }^{1}$ Evidence Act 1995 (NSW) s 89A, as inserted by Evidence Amendment (Evidence of Silence) Act 2013 (NSW) sch 1 item 2.

${ }^{2}$ Petty v The Queen (1991) 173 CLR 95 [2] (Mason CJ, Deane, Toohey and McHugh JJ).

${ }^{3}$ Ibid.

${ }^{4}$ Ibid.

${ }^{5}$ Sanchez v R (2009) 196 A Crim R 472 [71]; Stephen Odgers, Uniform Evidence Law (Thomson Reuters, 10 ${ }^{\text {th }}$ ed, 2012) [1.3.5680].

${ }^{6}$ Evidence Act 1995 (NSW) s 89.

${ }^{7}$ Ibid s 9.

${ }^{8}$ See, eg, the Australian Security Intelligence Organisation Act 1979 (Cth) s 34L, the Australian Crime Commission Act 2002 (Cth) s 30 and the Independent Commission against Corruption Act 1988 (NSW) ss 21-22, in which statutes the federal and NSW Parliaments have enacted legislation designed to override the common law right to silence.

${ }^{9}$ Evidence Act 1995 (NSW) s 89A(1).

${ }^{10}$ Petty v The Queen (1991) 173 CLR 95 [2] (Mason CJ, Deane, Toohey and McHugh JJ).

${ }^{11}$ See, eg, New South Wales Law Reform Commission, The Right to Silence, Report No 95 (2000)); David Harmer et al, Submission on Exposure Draft: Evidence Amendment (Evidence of Silence) Bill 2012 (September 2012) <https://law.anu.edu.au/sites/all/files/users/u4810180
} 
been unsuccessful in swaying the legislature, an analysis of similar legislation in the United Kingdom, from which the new provision was modelled, indicates that section 89A will introduce significant complexity and inefficiency into the law, without any real benefit. Unlike the previously applicable section 89, section $89 \mathrm{~A}$ is highly complex, being subject to numerous restrictions and limitations, the interpretation of which remains unclear. Further, the benefits of the new legislation are minimal and evidence of silence has only limited evidentiary value in the trial of offenders. Therefore, the amount of judicial time that can be expected to be spent on section $89 \mathrm{~A}$, and the significant uncertainty regarding its interpretation mean that close monitoring of the provision in the short term is warranted and may ultimately justify a review of the legislation at some later stage.

The first part of this article outlines the amendment to the New South Wales legislation along with the equivalent legislation enacted in the United Kingdom. It then briefly reviews the rationale behind the right to silence, in order to demonstrate its fundamental nature, against which its amendment must be assessed.

The second part explains the arguments supporting the use of silence as evidence in criminal proceedings, with reference to the purported rationale for the amendment and to existing criticisms of it, from a theoretical and policy perspective. These criticisms show that the purported benefits will not be realised, or will at best be minimal.

The last part attempts to fill a gap in the literature by undertaking a detailed comparative analysis of the new provision with reference to equivalent legislation in the United Kingdom. This analysis will focus on the likely operation of the new provision in New South Wales.

\section{A The New Legislation}

On 25 March 2013 the Evidence Amendment (Evidence of Silence) Act 2013 (NSW) passed unaltered through both houses of the New South Wales Parliament. This legislation inserted section 89A into the Evidence Act 1995 (NSW) in relation to the use of silence as evidence in criminal proceedings. The legislation was enacted as part of a package, together with the Criminal Procedure Amendment (Mandatory Pre-Trial Defence Disclosure) Act 2013

\footnotetext{
/submission_on_silence_-_hamer_et_al.pdf $>$ ); New South Wales Bar Association, Re: The Right to Silence, (28 September 2012) <http://www.nswbar.asn.au/circulars/2012/sep/r2s. pdf $>$.
} 
(NSW). Both Acts were proclaimed on 1 September 2013 and commenced operation on 1 September 2013.

In its enacted form, section 89A provides as follows:

(1) In a criminal proceeding for a serious indictable offence, such unfavourable inferences may be drawn as appear proper from evidence that, during official questioning in relation to the offence, the defendant failed or refused to mention a fact:

(a) that the defendant could reasonably have been expected to mention in the circumstances existing at the time, and

(b) that is relied on in his or her defence in that proceeding.

(2) Subsection (1) does not apply unless:

(a) a special caution was given to the defendant by an investigating official who, at the time the caution was given, had reasonable cause to suspect that the defendant had committed the serious indictable offence, and

(b) the special caution was given before the failure or refusal to mention the fact, and

(c) the special caution was given in the presence of an Australian legal practitioner who was acting for the defendant at that time, and

(d) the defendant had, before the failure or refusal to mention the fact, been allowed a reasonable opportunity to consult with that Australian legal practitioner, in the absence of the investigating official, about the general nature and effect of special cautions.

(3) It is not necessary that a particular form of words be used in giving a special caution.

(4) An investigating official must not give a special caution to a person being questioned in relation to an offence unless satisfied that the offence is a serious indictable offence.

(5) This section does not apply:

(a) to a defendant who, at the time of the official questioning, is under 18 years of age or is incapable of understanding the general nature and effect of a special caution, or 
(b) if evidence of the failure or refusal to mention the fact is the only evidence that the defendant is guilty of the serious indictable offence.

(6) The provisions of this section are in addition to any other provisions relating to a person being cautioned before being investigated for an offence that the person does not have to say or do anything. The special caution may be given after or in conjunction with that caution.

(7) Nothing in this section precludes the drawing of any inference from evidence of silence that could properly be drawn apart from this section.

(8) The giving of a special caution in accordance with this section in relation to a serious indictable offence does not of itself make evidence obtained after the giving of the special caution inadmissible in proceedings for any other offence (whether or not a serious indictable offence).

(9) In this section:

"official questioning" of a defendant in relation to a serious indictable offence means questions put to the defendant by an investigating official who at that time was performing functions in connection with the investigation of the commission, or possible commission, of the serious indictable offence.

"special caution" means a caution given to a person that is to the effect that:

(a) the person does not have to say or do anything, but it may harm the person's defence if the person does not mention when questioned something the person later relies on in court, and

(b) anything the person does say or do may be used in evidence.

Thus, section 89A provides that in certain circumstances the trier of fact may draw such unfavourable inferences as appear proper from evidence that the defendant ${ }^{12}$ failed or refused to mention a fact during official questioning. ${ }^{13}$ The unfavourable inferences may be drawn only where the defendant could reasonably have been expected to mention the relevant fact in the circumstances existing at the time of the official questioning and where the defendant later relies on the relevant fact in his or her defence in the proceedings. ${ }^{14}$ The

\footnotetext{
12 The New South Wales legislation uses the term 'defendant', while the equivalent United Kingdom legislation uses the term 'accused'. This article will refer to the 'defendant' when discussing the New South Wales provision, and to the 'accused' when discussing the United Kingdom provision.

${ }^{13}$ Evidence Act 1995 (NSW) s 89A(1).

${ }^{14}$ Ibid.
} 
legislation defines 'official questioning' as questions put by an investigating official who was at the time performing his or her functions in connection with the investigation of a serious indictable offence. ${ }^{15}$ Further, the section applies only to serious indictable offences, which are defined in section four of the Crimes Act 1900 (NSW) as offences which are punishable by a term of imprisonment of five years or more. This will limit the application of section 89A to proceedings before the Supreme or District Court. ${ }^{16}$

Section $89 \mathrm{~A}$ is also limited by a number of exceptions. First, inferences may be drawn only where a 'special caution' ${ }^{17}$ has been given to the defendant by an investigating official. The special caution must be given once the investigating official has reasonable cause to suspect the defendant of a serious indictable offence and before the failure to disclose. The term 'special caution' is defined in the new provision. ${ }^{18}$ While particular words are not necessary, the special caution must warn the defendant that, although they do not have to do or say anything, it may harm their defence not to mention something that they later rely upon in court, and that anything they do say or do may be used in evidence. ${ }^{19}$ The special caution must also be provided in the presence of an Australian legal practitioner who is at the time acting for the defendant and who has had a reasonable opportunity to consult with the defendant. ${ }^{20}$ This limitation was introduced in response to criticisms that the special caution would put undue pressure on the defendant to speak,,$^{21}$ and to ensure that accused persons understood the potential consequences of their silence. ${ }^{22}$ Section 89A will also not apply to defendants under the age of 18 years or those who are incapable of understanding the special caution. ${ }^{23}$ Finally, the evidence of silence cannot be relied upon where it is the only evidence of a person's guilt. ${ }^{24}$ Therefore, silence

\footnotetext{
${ }^{15}$ Ibid s 89A(9).

${ }^{16}$ Criminal Procedure Act 1986 (NSW) s 8.

${ }^{17}$ Evidence Act 1995 (NSW) s 89A(2).

${ }^{18}$ Ibid s 89A(9).

${ }^{19}$ Ibid s 89A(3).

${ }^{20}$ Ibid s 89A(2).

${ }^{21}$ See under heading II: Silence as Evidence, below.

${ }^{22}$ Unlike the position in England and Wales, accused persons in New South Wales do not have ready access to duty solicitors in police stations who can provide advice to accused about their legal rights. As the Law Reform Commission acknowledged at [2.139] of Report No 95, current legal aid funding would be insufficient to provide such duty solicitors and is unlikely to be increased for this purpose. See New South Wales Law Reform Commission, above n 11, [2.139].

${ }^{23}$ Evidence Act 1995 (NSW) s 89A(5)(a).

${ }^{24}$ Ibid s 89A(5)(b).
} 
must be supported by other evidence in order to lead to a conviction of the defendant.

The new provision was modelled on equivalent United Kingdom legislation, ${ }^{25}$ which similarly allows a court to draw adverse inferences from the accused person's failure to mention facts when questioned or charged. ${ }^{26}$ That legislation - section 34 of the Criminal Justice and Public Order Act 1994 (UK) provides that the court or jury 'may draw such inferences ... as appear proper' 27 where the accused 'failed to mention any fact later relied upon in his defence' ${ }^{28}$ The relevant fact must also be one which, in the circumstances, the accused person could reasonably have been expected to mention. ${ }^{29}$ Unlike the New South Wales provision, section 34 applies to a failure to mention such facts either 1) prior to being charged, when being questioned by a constable, 2) upon being charged with an offence or 3) upon the accused/suspect being officially informed that he or she might be prosecuted for an offence. ${ }^{30}$ As is the case in New South Wales, section 34 includes a provision that the accused person must first have been allowed an opportunity to consult a solicitor, ${ }^{31}$ and that the accused was administered the relevant caution. ${ }^{32}$ However, unlike the position in New South Wales, the relevant caution does not need to be given in the presence of a legal practitioner. Also, section 34 does not expressly exclude the application of the provision to accused persons under a certain age or those who do not understand the relevant caution. ${ }^{33}$ Finally, section 38(3) of the United Kingdom legislation provides that an accused person cannot be convicted solely upon inferences drawn under section 34, which has the same effect as section $89 \mathrm{~A}(5)(\mathrm{b})$ of the New South Wales provision. ${ }^{34}$

The policy considerations behind the enactment of both provisions were quite similar. Parliamentary members of the New South Wales Liberal Party justified

\footnotetext{
${ }^{25}$ ABC News, 'O'Farrell Government overhauls "right to silence"', 7:30 Report, 19 August 2012 (Quentin Dempster) <http:// www.abc.net.au/news/2012-08-19/ofarrell-governmentoverhauls-right-to-silence /4208348>.

${ }^{26}$ Criminal Justice and Public Order Act 1994 (UK).

27 Ibid s 34(2).

28 Ibid s 34(1).

29 Ibid.

${ }^{30}$ Ibid ss 34(1)(a)-(b).

31 Ibid s 34(2A).

${ }^{32}$ Ibid s 34(1)(a).

33 Ibid s 34.

34 Ibid s 38.
} 
section $89 \mathrm{~A}$ as 'simply a matter of common sense'. ${ }^{35}$ The Attorney-General, Greg Smith, echoed the Liberal Party arguments, stating that section 89A was primarily aimed at breaking down the perceived 'wall of silence" ${ }^{36}$ behind which suspects at the "higher end of criminal activity" ${ }^{37}$ were thought to hide. Greg Smith also argued that the new legislation would prevent accused persons from frustrating criminal justice by exercising their right to silence, thus reducing delays in criminal trials, producing efficiency and promoting 'fairness' ${ }^{38}$ for both the prosecution and the accused. These justifications are very similar to those relied upon by the Conservative Party in the United Kingdom. They too referred to the legislation as a 'restoration of common sense', ${ }^{39}$ and justified the new provision as likely to increase conviction rates by preventing the guilty from using silence as a shield. ${ }^{40}$

Interestingly, the reference in the Second Reading Speech of Greg Smith to the notion of 'fairness' seems to directly contradict criticisms that the new legislation will undermine the right to a fair trial. The High Court of Australia in Dietrich $v R$ discussed at length the concept of the fair trial, ${ }^{41}$ confirming earlier decisions that the right to a fair trial is a fundamental common law right in Australia. ${ }^{42}$ The Court accepted that, while the insistence on a fair trial is firmly established as a 'central pillar' of criminal justice, ${ }^{43}$ the precise principles that constitute that right are not so clearly defined. ${ }^{44}$ The question becomes how far the right to a fair trial extends on the facts of each case. This is because in Australia there is no exhaustive or comprehensive definition of the attributes of a fair trial. ${ }^{45}$ Thus, what is 'fair' remains uncertain. Nevertheless, the juxtaposition between what Parliament considers 'fair' and what critics argue is required for a fair trial, shows the clear disparity between different concepts of fairness. It also highlights the need to balance the competing interests of the

\footnotetext{
${ }^{35}$ New South Wales, Parliamentary Debates, Legislative Council, 20 March 2013, 1 (Michael Gallacher); New South Wales, Parliamentary Debates, Legislative Council, 13 March 2013, 85 (Greg Smith).

${ }^{36}$ New South Wales, Parliamentary Debates, Legislative Council, 13 March 2013, 87 (Greg Smith).

${ }^{37}$ Ibid.

${ }^{38}$ Ibid $85,96$.

${ }^{39}$ United Kingdom, Parliamentary Debates, House of Commons, 11 January 1994, 80 (Betty Boothroyd).

${ }^{40}$ Ibid 44, 86.

${ }^{41}$ Dietrich v R (1992) 177 CLR 292.

${ }^{42}$ See, eg, Barton v R (1980) 147 CLR 75; Jago v District Court of New South Wales (1989) 168 CLR 23.

${ }^{43}$ Dietrich v R (1992) 177 CLR 292, 298 (Mason CJ and McHugh J).

${ }^{44}$ Ibid 300 (Mason CJ and McHugh J), 326 (Deane J), 353 (Toohey J), 362-4 (Gaudron J).

${ }^{45}$ Ibid 300 (Mason CJ and McHugh J), 353 (Toohey J).
} 
prosecution against those of the accused. ${ }^{46}$ The new provision attempts to strike that balance of fairness more in favour of the prosecution than was previously the case, by encouraging early disclosure. The question which remains, and which cannot be definitively answered, is whether this new balance actually produces fairness between the parties.

\section{B The Rationale for the Right to Silence}

The right to silence is not a single legal principle, but rather consists of 'a collection of principles and rules'. ${ }^{47}$ These principles include the right against self-incrimination, the right to refuse to assist the prosecution and the right to not disclose one's defence until trial. ${ }^{48}$ However, these principles have been substantially narrowed in recent years as legislators have sought to increase the 'efficiency' of the court system. ${ }^{49}$ This is particularly evident from the enactment of Division 3 of the Criminal Procedure Act 1986 (NSW) in 2009, which requires 'certain pre-trial disclosure' by parties 'in order to reduce delays in proceedings'. ${ }^{50}$ Further, many investigative authorities have now been empowered to compel disclosure, such compulsion overriding any previously existing right to silence. ${ }^{51}$ While the right to silence has always been subject to limitations and exceptions, even at common law, ${ }^{52}$ the recent trend has been to increase such limitations, further restricting what remained of the right to silence in Australian law. Thus, the section 89A enactment forms part of a broader trend.

\footnotetext{
${ }^{46}$ See, eg, James Jacob Spigelman, 'The Truth Can Cost Too Much: The Principle of a Fair Trial' (2004) 78 Australian Law Journal 29, 44.

${ }^{47}$ Azzopardi v The Queen (2001) 205 CLR 50 [7] (Gleeson CJ).

${ }^{48}$ Barbara Ann Hocking and Laura Leigh Manville, 'What of the Right to Silence: Still Supporting the Presumption of Innocence, or a Growing Legal Fiction?' (2001) 1(1) Macquarie Law Journal 63, 89; K A Cavanaugh, 'Emergency Rule, Normalcy Exception: The Erosion of the Right to Silence in the United Kingdom' (2002) 35 Cornell International Law Journal 491, 492.

49 Anthony Gray, 'Constitutionally Heeding the Right to Silence in Australia' (2013) 39(1) Monash University Law Review 156, 163.

${ }^{50}$ Criminal Procedure Act 1986 (NSW) s 134(1).

${ }^{51} \mathrm{See}$, eg, Australian Security Intelligence Organisation Act 1979 (Cth) s 34L; Australian Crime Commission Act 2002 (Cth) s 30; Independent Commission against Corruption Act 1988 (NSW) ss 21-22.

${ }^{52}$ Weissensteiner v The Queen (1993) 178 CLR 217, [51]-[53]; Azzopardi v The Queen (2001) 205 CLR 50, [68]; New South Wales Law Reform Commission, above n 11, [2.8]; Steven Greer, 'The Right to Silence: A Review of the Current Debate' (1990) 53(6) Modern Law Review 709, 712.
} 
Although the right to silence is recognised in a number of jurisdictions, ${ }^{53}$ its origins and justifications are not entirely certain. The most widely accepted theory is that the right to silence developed in $16^{\text {th }}$-century England out of the significant opposition to the use of the inquisitorial oath by the ecclesiastical courts. ${ }^{54}$ The inquisitorial procedure required accused persons to make a statement on oath with respect to accusations made against them. ${ }^{55}$ It became the subject of much hostility as critics argued that it was open to abuse by the arresting authorities and examining justices and was believed to produce erroneous confessions. ${ }^{56}$ By the early $17^{\text {th }}$ century, argument in opposition to the inquisitorial oath began to rely upon the Magna Carta and the common law, which limited the Crown's sovereignty. ${ }^{57}$ The ecclesiastical courts during the reign of Charles 1 continued to impose the oath despite this opposition. In a landmark case in 1639, the Star Chamber convicted John Lilburne of contempt for refusing to take the oath. As a reaction to this conviction, and with the political tide turning against the Crown, Parliament in 1641 ruled Lilburne's sentence illegal, abolished the ecclesiastical courts and barred the use of the oath in penal cases. ${ }^{58}$ Thus, the right to silence was firmly in place by the late 17 th century. ${ }^{59}$

Other theories suggest that the right to silence originated much earlier from Roman-Canon law and applied first to witnesses as a right against selfincrimination. MacNair proposes that the right was then extended in the late $17^{\text {th }}$ century into a general right to silence for persons accused of a crime. ${ }^{60}$ It was justified as removing the conflict of conscience between giving a statement on oath and protecting oneself against punishment. ${ }^{61}$ Other legal historians trace the right back to criminal procedures adopted in the Middle Ages, which entirely excluded confession evidence on the basis that it was unreliable. ${ }^{62} \mathrm{On}$

${ }^{53}$ Canada Act 1982 (UK) c 11, sch B, pt 1 ('Canadian Charter of Rights and Freedoms') ss 7, 11(c); United States Constitution amend V; Constitution (India) 1949, art 20(3); Murray v United Kingdom (European Court of Human Rights, Grand Chamber, Application No 18731/91, 8 February 1996) [45].

54 Greer, above n 52, 710; J Wood and A Crawford, 'The Right of Silence: The Case for Retention' [1989] London: Civil Liberties Trust 37, 42.

${ }^{55}$ Gregory O'Reilly, 'England Limits the Right to Silence and Moves towards an Inquisitorial System of Justice' (1994) 85(2) Journal of Criminal law and Criminology 402, 410-11.

${ }^{56}$ Ibid 421-2; New South Wales Law Reform Commission, above n 11, [2.3]-[2.5].

${ }^{57}$ O'Reilly, above $\mathrm{n} 55,415$.

${ }^{58}$ Ibid $417-8$.

${ }^{59}$ Ibid 418.

${ }^{60}$ M R T MacNair, 'The Early Development of the Privilege against Self-incrimination' (1990) 10(1) Oxford Journal of Legal Studies 66. See also Greer, above n 52, 710-11.

${ }^{61}$ MacNair, above n 60.

${ }^{62}$ Ibid. 
the other hand, the 1981 Royal Commission on Criminal Procedure, chaired by Sir Cyril Philips, places the origins of the right to silence much later, in the $19^{\text {th }}$ century, suggesting that it was implemented to offset disadvantages that the accused experienced due to the power imbalance between the accused and the State. ${ }^{63}$

The right to silence was nevertheless adopted into Australian jurisprudence upon settlement. ${ }^{64}$ In the decision of the High Court of Australia in Petty $v$ The Queen, ${ }^{65}$ the Court expressly confirmed its application in Australian law, referring to it as a 'fundamental rule of the common law'. ${ }^{66}$ The Court held that the drawing of adverse inferences against accused persons because they had exercised their right to silence was impermissible ${ }^{67}$ and amounted to a source of entrapment. ${ }^{68}$ In subsequent decisions the Court has held that it will often be appropriate for a judge to give directions discouraging a jury from drawing any adverse inferences from evidence of silence. ${ }^{69}$ Legislation has also been enacted in most Australian jurisdictions which expressly precludes the court in criminal proceedings drawing adverse inferences from evidence of silence. ${ }^{70}$ While section 89 does allow the tendering of evidence about which the accused remained silent during official questioning, it will be permissible only where the purpose of such tender is not solely to draw adverse inferences from the silence.

Further, these provisions are confined to pre-trial silence and do not affect the right of the accused to remain silent at the trial, which remains intact. Although inroads may have been made into the right to silence in some 'rare and exceptional' cases at common law, ${ }^{71}$ and through statutory reform governing pre-trial disclosure, ${ }^{72}$ the entitlement of accused persons not to have inferences

${ }^{63}$ Ibid; Andrew L-T Choo, Evidence (Oxford University Press, $3^{\text {rd }}$ ed, 2012) 124-6. United Kingdom, Royal Commission on Criminal Procedure (Philips Commission), Command Paper (1981).

${ }^{64}$ Alex C Castles, 'The Reception and Status of English Law in Australia' (1963) 2(1) Adelaide Law Review 1, 2.

65 (1991) 173 CLR 95.

${ }^{66}$ Ibid [1] (Mason CJ, Deane, Toohey and McHugh JJ).

${ }^{67}$ Ibid [6] (Mason CJ, Deane, Toohey and McHugh JJ).

${ }^{68}$ Ibid.

${ }^{69} R v$ Hodge [2002] NSWCCA 10 (15 February 2002) [32].

${ }^{70}$ Evidence Act 1995 (Cth) s 89; Evidence Act 1995 (NSW) s 89; Evidence Act 2011 (ACT) s 89; Evidence Act 2008 (Vic) s 89; Evidence Act 2001 (Tas) s 89.

${ }^{71}$ Weissensteiner $v$ The Queen (1993) 178 CLR 217, [51]-[53]; Azzopardi v The Queen (2001) 205 CLR 50 [68]; New South Wales Law Reform Commission, above n 11, [2.8]; Greer, above n 52, 712 .

${ }^{72}$ See, eg, Criminal Procedure Act 1986 (NSW) Div 3. 
drawn against them because they had exercised their right to silence during police questioning remained protected in New South Wales by the application of section 89 , prior to the recent amendment. ${ }^{73}$

The policy considerations behind, and justifications for, the continued application of the right to silence provide reasons to resist any further restriction of the right. First, the right to silence corrects the power imbalance between the accused and the State. ${ }^{74}$ It forces the State, with its greater resources, to prove the case against the accused without relying upon the assistance of the accused themselves. It is also seen as necessary to safeguard the autonomy and liberty of individuals, ${ }^{75}$ and to protect their privacy by not prying into their conscience and forcing them to swear to potentially incriminating evidence. ${ }^{76}$ Therefore it removes the internal conflict between the desire not to incriminate oneself and the perceived need to commit perjury or to act in contempt of court. Also, advocates of the accusatorial approach argue that, where the right to silence is upheld, the accusatorial approach is less prone to abuse by authorities. This is because it forces the prosecution to rely on independent evidence of guilt, rather than evidence from the accused. ${ }^{77}$ For these reasons, it is generally accepted that the right to silence is inherent in the right to a fair trial. ${ }^{78}$

It is against this background and these justifications, that the amendment to the Evidence Act 1995 (NSW) must be assessed.

\section{Silence As EVIDENCE}

Despite courts labelling the right to silence as 'fundamental' to our system of criminal justice, ${ }^{79}$ the New South Wales Parliament has gradually restricted the right, most recently by the insertion of section 89A. The recent legislation was introduced as a response to several drive-by shootings in Western Sydney, during the investigation of which suspects had exercised their right to silence,

\footnotetext{
${ }^{73}$ Evidence Act 1995 (NSW) s 89A.

${ }^{74}$ O'Reilly, above n 55, 419-21.

${ }^{75}$ Michael Chaaya, 'The Right to Silence Reignited: Vulnerable Suspects, Police Questioning and Law and Order in New South Wales' (1998) 22 Criminal Law Journal 82, 84.

${ }^{76}$ O'Reilly, above n 55, 422.

${ }^{77}$ Ibid 421-2.

${ }^{78}$ Petty v The Queen (1991) 173 CLR 95; Murray v United Kingdom (European Court of Human Rights, Grand Chamber, Application No 18731/91, 8 February 1996) [45].

${ }^{79} R$ v Reeves (1992) 29 NSWLR 109, 115 (Hunt CJ at CL); Petty $v$ The Queen (1991) 173 CLR 95, 128-9 (Gaudron J).
} 
allegedly creating difficulties for investigating police. ${ }^{80}$ Michael Gallacher, Minister for Police and Emergency, who introduced the Bill to Parliament, argued that the package of legislation, which included both mandatory pre-trial disclosure and the new section 89A, would result in a 'crackdown on crime' by preventing accused persons frustrating criminal justice by using the right to silence as a shield. ${ }^{82} \mathrm{Mr}$ Gallacher, in his Second Reading Speech, suggested that offenders were exploiting the right, hindering police investigations and lengthening proceedings and that this in turn was leading to avoidable acquittals. ${ }^{83}$ Thus, the amendment was justified as 'simply a matter of common sense', ${ }^{84}$ which would guarantee 'fairness' for both the prosecution and the accused, ${ }^{85}$ and make the trial process more efficient. ${ }^{86}$

However, whether the new provision achieves these purported objectives remains controversial. The findings of empirical studies have undermined many of the claimed benefits of this type of legislation. In particular, research undertaken in the United Kingdom in the early 1990s, indicates that only between four and seven per cent of accused persons exercised their right to silence when questioned by police. ${ }^{87}$ Further, accused persons who exercised the right to silence were no less likely to be convicted than those who

\footnotetext{
${ }^{80}$ ABC News, above n 25.

${ }^{81}$ Barry O'Farrell, 'Crime Crackdown: "Right to Silence" Law Toughened' (Media Release, 14 August2012) <http://www.premier.nsw.gov.au/sites/default/files/CRIME\%20CRACKDOWN \%20RIGHT\%20TO\%20SILENCE\%20LAW\%20TOUGHENED.pdf >.

${ }^{82}$ New South Wales, Parliamentary Debates, Legislative Council, 20 March 2013, 1, 7 (Michael Gallacher); New South Wales, Parliamentary Debates, Legislative Council, 13 March 2013, 85, 96 (Greg Smith).

${ }^{83}$ David Hamer and Gary Edmond, 'When You Say Nothing At All: NSW and the Right to Silence', The Conversation, 22 March $2013<\mathrm{http}$ ///theconversation.com/when-you-saynothing-at-all-nsw-and-the-right-to-silence-12962>; Barry O'Farrell, 'Crime Crackdown: "Right to Silence" Law Toughened' (Media Release, 14 August 2012) <http://www.premier.nsw.gov.au/sites/default/files/CRIME\%20CRACKDOWN \%20RIGHT\%20TO\%20SILENCE\%20LAW\%20TOUGHENED.pdf >; New South Wales, Parliamentary Debates, Legislative Council, 20 March 2013 (Michael Gallacher).

${ }^{84}$ New South Wales, Parliamentary Debates, Legislative Council, 20 March 2013, 1 (Michael Gallacher); New South Wales, Parliamentary Debates, Legislative Council, 13 March 2013, 85 (Greg Smith).

${ }^{85}$ New South Wales, Parliamentary Debates, Legislative Council, 13 March 2013, 96 (Greg Smith).

${ }^{86}$ Ibid 85, 96 (Greg Smith).

${ }^{87}$ United Kingdom, Royal Commission on Criminal Justice, The Right to Silence in Police Interrogation: A Study of Some of the Issues Underlying the Debate (1993) 17, 20; J Coldrey, 'The Right to Silence: Should It Be Curtailed or Abolished?' (1991) 20 Anglo-American Law Review 51, 54-5.
} 
cooperated ${ }^{88}$ Those studies also demonstrated that silence was related to the failure to sustain a conviction in less than four per cent of cases where no further action was taken, and in under 10 per cent of acquittals or dropped cases. ${ }^{89}$ More recent Australian studies have also found that the right to silence is not widely exploited and does not impede the conviction of offenders. ${ }^{90}$ The earlier United Kingdom studies into the impact of adverse inference legislation internationally, which examined in particular Singapore and Northern Ireland, indicate that the new model would have little or no impact on convictions or the number of accused people who remain silent. ${ }^{91}$ Thus, the empirical evidence does not support the arguments made by Parliament.

The legislation also potentially impinges upon fundamental rights. Critics argue that the legislation effectively lowers the prosecution's burden of proof and undermines the presumption of innocence..$^{92}$ Currently, the Crown alone must prove criminal allegations, beyond reasonable doubt. ${ }^{93}$ This forms a cornerstone of criminal justice and is essential to the fair trial. ${ }^{94}$ Although the new provision does not reverse the onus of proof or the presumption of innocence, it arguably forces the accused in effect to give evidence, whether in the form of actual evidence given in the police interview or by way of the prosecution being permitted to ask the trier of fact to draw adverse inferences from evidence of the accused person's failure to disclose something later relied upon at trial. ${ }^{95}$ Therefore this new legislation arguably provides the prosecution with an 'evidentiary building block ${ }^{96}$ in proving its case. ${ }^{97}$ If it is true that

\footnotetext{
${ }^{88}$ United Kingdom, Royal Commission, above n 87, 17, 24, 40, 53; Coldrey, above n 87, 54-5.

${ }^{89}$ United Kingdom, Royal Commission, above n 87, 17, 74.

${ }^{90}$ Brendon Murphy and Simon Bronitt, 'Pros and Cons of the Right to Silence: A Fundamental Right or Legal Fiction?' (2009) 21(1) Legal Date 10, 10-11; New South Wales Law Reform Commission, above n 11, [2.43], [2.63]-[2.68], [2.138].

${ }^{91}$ United Kingdom, Royal Commission, above n 87, 17, 73-80.

${ }^{92} \mathrm{~K}$ A Cavanaugh, 'Emergency Rule, Normalcy Exception: The Erosion of the Right to Silence in the United Kingdom' (2002) 35 Cornell International Law Journal 491, 493; John D Jackson, 'Silence and Proof: Extending the Boundaries of Criminal Procedure in the United Kingdom' 2001 (5) International Journal of Evidence and Proof 145, 152-7; O'Reilly, above n 55, 402; Steven Greer, 'The Right to Silence: a Review of the Current Debate' (1990) 53(6) Modern Law Review 709, 725-6.

${ }^{93}$ Helen Dale, 'I'll Take a Fifth of That: The Right to Silence and the Presumption of Innocence' (2008) 52(1) Quadrant 57, 57.

${ }^{94}$ Lee v New South Wales Crime Commission (2013) 87 ALJR 1082 [159], [174]-[193]; X7v Australian Crime Commission (2013) 87 ALJR 858, 883.

${ }^{95}$ Elizabeth Stone, 'Calling a Spade a Spade: the Embarrassing Truth about the Right to Silence' (1998) 22 Criminal Law Journal 17, 19; Petty v The Queen (1991) 173 CLR 95, 128-129.

${ }^{96}$ Chaaya, above $\mathrm{n} 75,91$.

${ }^{97}$ Ibid; Coldrey, above n 87, 59.
} 
section 89A will undermine the fair trial, then Parliament's suggestion that the legislation will produce 'fairness' for both the prosecution and the accused is undermined.$^{98}$ However, as discussed earlier, this raises the question of what is 'fair' in all of the circumstances.

Similarly, the new special caution may place 'irresistible pressure' 99 on the accused to speak. It could potentially lead to misunderstandings, false confessions and even ill treatment, which may in turn produce false convictions. ${ }^{100}$ In a pressured environment the accused may be more prone to ramble or lie, rather than honestly stating that they do not recall certain facts. ${ }^{101}$ Critics argue that the increased pressure of the special caution may amplify these effects, leading suspects to inadvertently incriminate themselves. ${ }^{102}$ By pressuring accused persons to provide a defence immediately, the new provision will also encourage false defences. Seidmann and Stein argue that this will weaken the uncorroborated explanations made by innocent accused, as triers of fact are more likely to dismiss uncorroborated evidence by lumping it together with uncorroborated false defences. ${ }^{103}$ This could in effect produce more wrongful convictions as uncorroborated explanations are less likely to be accepted. ${ }^{104}$ Thus, the new legislation may lead to substandard criminal justice.

Finally, silence has minimal evidentiary value in criminal proceedings. ${ }^{105}$ This is because silence itself often does not provide direct probative evidence of the

\footnotetext{
98 New South Wales, Parliamentary Debates, Legislative Council, 20 March 2013, 7 (Michael Gallacher); New South Wales, Parliamentary Debates, Legislative Council, 13 March 2013, 96 (Greg Smith).

${ }^{99}$ Hocking and Manville, above n 48, 70; J D Heydon, 'Confessions and Silence' (1976) 7 Sydney Law Review 375, 387-9.

${ }^{100}$ Heydon, above n 99, 387-9; Chaaya, above n 75, 90-1; Greer, above n 52, 726-7.

${ }^{101}$ Heydon, above n 99, 388.

102 Ibid; Michelle Lam, 'Remaining Silent: A Fundamental Right' (2012) 50(9) Law Society Journal 17, 18.

${ }^{103}$ Daniel J Seidmann and Alex Stein, 'The Right to Silence Helps the Innocent: A GameTheoretic Analysis of the Fifth Amendment Privilege' (2000) 114 Harvard Law Review 430; Alex Stein, 'The Right to Silence Helps the Innocent: A Response to Critics' (2009) 30(3) Cardozo Law Review 1115.

${ }^{104}$ Seidmann and Stein, above n 103; Stein, above n 103.

${ }^{105}$ Diane J Birch, 'Suffering In Silence: A Cost-Benefit Analysis of s 34 of the Criminal Justice and Public Order Act 1994' [1999] Criminal Law Review 769, 773.
} 
elements of the offence, ${ }^{106}$ as it generally ${ }^{107}$ does not prove any fact in issue in the proceedings. ${ }^{108}$ Further, silence is equivocal and will not necessarily signify guilt. ${ }^{109}$ An accused person may have chosen to remain silent to hide unrelated embarrassing conduct, to protect others, because the person has poor communication skills or because of a fear that the person's statement may be distorted by police. ${ }^{110}$ Although section $89 \mathrm{~A}$ does not require an inference of guilt in all circumstances, it may inadvertently encourage triers of fact to infer guilt, by permitting such an inference even though the inference may not be justified. While it is arguable that silence may have some probative value in certain circumstances, ${ }^{111}$ for example where information surrounding the alleged offence is peculiarly within the knowledge of the defendant, the common law in Australia already caters for those limited situations. ${ }^{112}$ Therefore, as evidence of silence is generally irrelevant or only minimally probative, it will often be of only very limited evidentiary value. For these reasons, the new legislation provides, rightly, that silence may lead to an inference of guilt only when combined with other probative evidence, ${ }^{113}$ giving it no more than a supportive role in convicting offenders. ${ }^{114}$

\footnotetext{
${ }^{106}$ Simon Matters, 'Anything You Don't Say May Be Given in Evidence: Protecting the Interests of Justice or Emasculating a Fundamental Right?' (1998) 4(1) Deakin Law Review 49, 57. Note that the High Court of Australia held in Weissensteiner v The Queen (1993) 178 CLR 217, 228 that there may be instances at common law where the circumstances of the case are such that the allegation made against the accused calls for some explanation from the defendant, and the silence of the defendant in such circumstances may be probative. However, this relates primarily to 'at trial' silence, rather than 'pre-trial' silence.

${ }^{107}$ A failure to disclose to a police officer may itself be a fact in issue in the proceedings. See, eg, Law Enforcement (Powers and Responsibilities) Act 2002 (NSW) s 12, which makes it an offence to fail to comply with a request of an officer to disclose one's identity. However, these instances do not relate to 'serious indictable offences' and thus section 89A will not apply to such circumstances.

${ }^{108}$ Matters, above n 106, 58.

${ }^{109}$ Andrew Palmer, 'Guilt and the Consciousness of Guilt: The Use of Lies, Flight and Other 'Guilty Behaviour' in the Investigation and Prosecution of Crime' (1997) 21 Melbourne University Law Review 95, 106-7.

${ }^{110}$ Australian Law Reform Commission, Criminal Investigation, Report No 2 (1975) [150]; New South Wales Law Reform Commission, above n 11, [2.115]-[2.129].

${ }^{111}$ Charles Williams, 'Silence in Australia: Probative Force and Rights in the Law of Evidence' (1994) 110 Law Quarterly Review 629, 648.

112 Weissensteiner $v$ The Queen (1993) 178 CLR 217, 228, 231.

${ }^{113}$ R Munday, 'Inference from Silence and European Human Rights Law' [1996] Criminal Law Review 370; Birch, above n 105, 773; Evidence Act 1995 (NSW) s 89A(5)(b); Criminal Justice and Public Order Act 1994 (UK) s 38(3); Condron v United Kingdom (European Court of Human Rights, Chamber, Application No 35718/97, 2 May 2000).

${ }^{114} \mathrm{C}$ Theophilopoulos, 'The Evidentiary Value of Adverse Inferences from the Right to Silence' (2002) 15 South African Journal of Criminal Justice 321, 331-3.
} 
It is evident from this review that there has been considerable criticism of section 89A, and similar legislation enacted in other jurisdictions, from a theoretical point of view. The evidence also suggests that, despite parliamentary justifications, the new legislation can be expected to provide only very limited benefits, if any. However, it remains to be seen how this legislation will operate in practice. An analysis of the judicial operation of similar legislation in the United Kingdom will help predict how the legislation might operate in New South Wales and whether section 89A is justified.

\section{Comparative Analysis}

Section 34 of the Criminal Justice and Public Order Act (1994) UK, the equivalent United Kingdom legislation, has now been in operation for 19 years, ${ }^{115}$ having come into force on 10 April 1995. Despite judicial efforts to simplify the issues that have arisen, this section still represents a complex and unsettled area of law. Appellate courts in the United Kingdom have described the provision as a 'notorious minefield'. ${ }^{116}$ Given that section $89 \mathrm{~A}$ was modelled on section $34,{ }^{117}$ an analysis of that provision and how it has been applied in the United Kingdom should provide insight into how section 89A will operate in New South Wales.

Section 34 of the Criminal Justice and Public Order Act (1994) UK relevantly provides as follows:

(1) Where, in any proceedings against a person for an offence, evidence is given that the accused-

(a) at any time before he was charged with the offence, on being questioned under caution by a constable trying to discover whether or by whom the offence had been committed, failed to mention any fact relied on in his defence in those proceedings; or

(b) on being charged with the offence or officially informed that he might be prosecuted for it, failed to mention any such fact,

being a fact which in the circumstances existing at the time the accused could reasonably have been expected to mention when so questioned, charged or informed, as the case may be, subsection (2) below applies.

115 Criminal Justice and Public Order Act 1994 (UK).

${ }^{116}$ Beckles v United Kingdom [2002] I Eur Court HR 661 [6].

${ }^{117}$ ABC News, above $\mathrm{n} 25$. 
(2) Where this subsection applies-

(a) a magistrates' court inquiring into the offence as examining justices;

(b) a judge, in deciding whether to grant an application made by the accused under paragraph 2 of Schedule 3 to the Crime and Disorder Act 1998

(c) the court, in determining whether there is a case to answer;

and

(d) the court or jury, in determining whether the accused is guilty of the offence charged,

may draw such inferences from the failure as appear proper.

(2A) Where the accused was at an authorised place of detention at the time of the failure, subsections (1) and (2) above do not apply if he had not been allowed an opportunity to consult a solicitor prior to being questioned, charged or informed as mentioned in subsection (1) above.

(3) Subject to any directions by the court, evidence tending to establish the failure may be given before or after evidence tending to establish the fact which the accused is alleged to have failed to mention.

(4) This section applies in relation to questioning by persons (other than constables) charged with the duty of investigating offences or charging offenders as it applies in relation to questioning by constables; and in subsection (1) above "officially informed" means informed by a constable or any such person.

(5) This section does not-

(a) prejudice the admissibility in evidence of the silence or other reaction of the accused in the face of anything said in his presence relating to the conduct in respect of which he is charged, in so far as evidence thereof would be admissible apart from this section; or

(b) preclude the drawing of any inference from any such silence or other reaction of the accused which could properly be drawn apart from this section.

(6) This section does not apply in relation to a failure to mention a fact if the failure occurred before the commencement of this section. 
It is clear that section 34 is very similar to section $89 \mathrm{~A}$, exhibiting wording that is often identical and that has a similar effect. Both sections permit the trier of fact to draw 'such inferences' 118 or such 'unfavourable inferences' ${ }^{119}$ as 'appear proper ${ }^{120}$ from the defendant's or the accused's failure to disclose 'a fact', ${ }^{121}$ which they could 'reasonably have been expected to mention', ${ }^{122}$ and which they later rely upon in the proceedings. ${ }^{123}$ Given the almost identical wording of many of the key phrases of the provisions, it is clear that the United Kingdom case law will influence the application of section 89A in New South Wales. Also similar is the fact that inferences may not be drawn under either provision unless the accused has had an opportunity to consult with a solicitor. ${ }^{124}$ However in New South Wales a solicitor must be present when the defendant is administered the 'special caution'. ${ }^{125}$ The other difference between the provisions, which is relevant to this analysis, is that, unlike the New South Wales provision which applies only to a failure to disclose a fact 'during official questioning, ${ }^{126}$ section 34 applies to a failure to mention a fact either 1) prior to being charged, when being questioned by a constable, 2) upon being charged with an offence or 3) upon the accused/suspect being officially informed that he or she might be prosecuted for an offence. ${ }^{127}$

\section{A Judicial Directions}

Judicial directions highlight the complexity of the new legislation. Unless no reasonable jury would find that adverse inferences should be drawn, ${ }^{128}$ United Kingdom judges are required to provide a direction to the jury outlining how section 34 operates in the particular case. ${ }^{129}$ However, these directions are very complex and have become the subject of substantial appellate case law.

\footnotetext{
${ }^{118}$ Criminal Justice and Public Order Act 1994 (UK) s 34(2).

${ }^{119}$ Evidence Act 1995 (NSW) s 89A(1).

${ }^{120}$ Criminal Justice and Public Order Act 1994 (UK) s 34(2); Evidence Act 1995 (NSW) s $89 \mathrm{~A}(1)$.

${ }^{121}$ Note that neither piece of legislation includes a definition of 'fact'.

122 Criminal Justice and Public Order Act 1994 (UK) s 34(1); Evidence Act 1995 (NSW) s 89A(1)(a).

${ }^{123}$ Criminal Justice and Public Order Act 1994 (UK) s 34(1)(a); Evidence Act 1995 (NSW) s $89 \mathrm{~A}(1)(\mathrm{b})$.

${ }^{124}$ Criminal Justice and Public Order Act 1994 (UK) s 34(2A); Evidence Act 1995 (NSW) s $89 \mathrm{~A}(2)(\mathrm{d})$.

${ }^{125}$ Evidence Act 1995 (NSW) s 89A(2).

${ }^{126}$ Ibid s 89A(1).

${ }^{127}$ Criminal Justice and Public Order Act 1994 (UK) ss 34(1)(a)-(b).

${ }^{128} R v$ McGarry (1998) 3 All ER 805.

${ }^{129}$ Criminal Justice and Public Order Act 1994 (UK) s 34; Argent v R [1997] Crim LR 449.
} 
Particular difficulties arise with respect to the length and complexity of the direction and whether a misdirection will result in an unsafe conviction.

In the United Kingdom, the Crown Bench Book almost immediately introduced a section 34 guideline direction to assist judges. ${ }^{130}$ This practice is unusual and signifies how difficult this legislation is to understand and apply. ${ }^{131}$ The guideline direction itself consists of 10 pages including commentary, making it one of the most lengthy and complicated directions in the Crown Bench Books. ${ }^{132}$ The England and Wales Court of Appeal has stated that, although a detailed direction is necessary, the direction is of such length and detail that it actually promotes the drawing of adverse inferences from silence to a level that is inconsistent with the intention of the direction. ${ }^{133}$ This suggests to juries that section 34 should be given greater weight than 'common sense' might advise. Further, the sheer length of the direction makes it difficult for a jury to fully understand and apply it. The desire to avoid unwarranted confusion for juries ${ }^{134}$ has led appellate courts to discourage prosecutors from seeking to apply section 34 unless absolutely necessary in the circumstances of the case. ${ }^{135}$

In New South Wales, the Criminal Trial Courts Bench Book has now been updated to insert a cross-reference to Special Bulletin 31, which contains a discussion of section $89 \mathrm{~A} .{ }^{136}$ The previous guideline direction was relatively simple, consisting of 10 short paragraphs, including commentary. ${ }^{137}$ However, Special Bulletin 31 consists of an additional 12 paragraphs. The Bulletin highlights a number of complexities in the new section, particularly with reference to the issues which have arisen in the United Kingdom. While the Bulletin itself does not provide a guideline direction, it expressly refers to the United Kingdom guideline direction and therefore imports the perceived issues that have arisen under section 34, including the fact that the length and

\footnotetext{
${ }^{130}$ Birch, above n 105, 772; United Kingdom, Crown Court Bench Book: Directing the Jury (United Kingdom, Judicial Studies Board, 2010) [15-427].

${ }^{131}$ Birch, above $\mathrm{n} 105,772$.

${ }^{132}$ Paul Roberts and Adrian Zuckerman, Criminal Evidence (Oxford University Press, $2^{\text {nd }} e d$, 2010) 571.

${ }^{133} R$ v Bresa [2005] EWCA Crim 1414 (26 May 2005) [4]-[5].

${ }^{134}$ Ibid.

${ }^{135}$ Brizzalari v $R$ [2004] EWCA Crim 310 (19 February 2004) [57].

136 Judicial Commission of New South Wales, Criminal Trial Courts Bench Book (New South Wales, Judicial Commission, 2012) [4-100]-[4-130]; Judicial Commission of New South Wales, Special Bulletin 31 'Right to silence - The Effect of s 89A of the Evidence Act 1995', (August 2013) <http://www.judcom.nsw.gov.au/publications/benchbks/criminal/special_ bulletin_31.html>.

137 Judicial Commission of New South Wales, Criminal Trial Courts Bench Book (New South Wales, Judicial Commission, 2012).
} 
complexity of the direction is thought to cause confusion for juries, and elevate the perceived importance of the provision to juries. Recent Australian reports into judicial directions generally have concluded that jury directions are already overly complex, confusing and even unintelligible to juries. ${ }^{138}$ Thus the additional length and complexity of the section $89 \mathrm{~A}$ judicial direction is likely to amplify this issue, causing additional confusion for jurors.

In the United Kingdom, the content of the section 34 direction has become a significant source of appellate review. Courts originally considered that, because the provision makes inroads into a right previously considered fundamental, any misdirection was of grave importance. In a number of cases convictions have been deemed unsafe because of a judge's misdirection in relation to section 34, despite a very strong case for the Crown. ${ }^{139}$ However, the England and Wales Court of Appeal has now decided, in the decision of Boyle, that a misdirection in relation to section 34 will not automatically mean that the conviction was unsafe. ${ }^{140}$

In Boyle the two accused were convicted of murder and sentenced to life imprisonment. While both the prosecution and the court accepted that there had been a significant misdirection in relation to section $34,{ }^{141}$ the appeal court nevertheless found that the convictions were safe. ${ }^{142}$ The case involved very strong circumstantial evidence, including evidence that both accused dealt in drugs with the victim, were seen using a car and gun that were linked to the murder, that the co-accused had unexplained injuries, and that the deceased's blood was found on clothing and glasses belonging to both of the accused. Boyle gave four 'no comment' interviews to police, on the basis of legal advice. Upon being charged, Boyle told police that he, the victim and the co-accused had injected themselves with drugs, thus purportedly explaining the blood evidence. Boyle denied any involvement in the murder and made no further

\footnotetext{
${ }^{138}$ Queensland Law Reform Commission, ‘A Review of Jury Directions' (Working Paper No 66, Queensland Law Reform Commission, March 2009) [6.3]-[6.6], [7.1]-[7.9]; Lily Trimboli, 'Juror Understanding of Judicial Instructions in Criminal Trials' (2008) 119 Crime and Justice Bulletin 1; ABC News, 'Judges Call for End to 'Unintelligible' Jury Directions', 7pm TV News VIC, 4 October 2012 (Sarah Farnsworth) <http://www.abc.net.au/news/2012-10-03/judgescall-for-end-to-27unintelligible27-jury-directions/4293832>; Zoneff $v$ The Queen (2000) 200 CLR 234, [66]-[67].

${ }^{139} R v$ Boyle [2006] EWCA Crim 2101 (25 August 2006) [6]; $R v$ Bresa [2005] EWCA Crim 1414 (26 May 2005); Condron v United Kingdom (European Court of Human Rights, Chamber, Application No 35718/97, 2 May 2000); Beckles v United Kingdom [2002] I Eur Court HR 661; $R v$ Moshaid [1998] Crim LR 420.

${ }^{140} R v$ Boyle [2006] EWCA Crim 2101 (25 August 2006) [14].

${ }^{141}$ Ibid [1], [34].

${ }^{142} R v$ Boyle [2006] EWCA Crim 2101 (25 August 2006) [44].
} 
comment. At the trial, Boyle gave oral evidence, consistent with his interview with police, but also explained that at the time of the murder he and the coaccused had been hunting a badger and that their gun had accidentally discharged, causing injuries to the co-accused. The trial judge gave direction to the jury about the application of section 34 to the 'no comment' interviews and the reliance on legal advice. ${ }^{143}$

The Court of Appeal found, and both parties accepted, that the direction was deficient. The nature of the deficiency was that the trial judge had erroneously failed to state that an inference could be drawn only if the jury was satisfied that the real reason for the silence was that the accused did not have an answer which would stand up to scrutiny, ${ }^{144}$ and that the judge had failed to outline which precise facts could give rise to the inference. ${ }^{145}$ Despite the deficiency, the Court of Appeal found that the convictions were safe. Unlike the European Court of Human Rights, ${ }^{146}$ the Court of Appeal stated that an 'absolutist approach' - that convictions would always be unsafe where there was a misdirection in relation to section 34 - was not necessary. ${ }^{147}$ Instead, a conviction may be deemed to be safe if the court finds that the jury was 'bound to convict', despite the misdirection. ${ }^{148}$ In Boyle, the Court held that the direction given was actually in favour of the accused, as it did not outline all of the facts which could have given rise to a section 34 inference and it placed a strong emphasis on legal advice. ${ }^{149}$ Thus, according to the Court of Appeal, if the correct direction had been given - outlining all the facts from which an inference might be drawn - the jury would have been even more likely to draw unfavourable inferences from the silence than on the basis of the direction that they were in fact given. ${ }^{150}$ More importantly, the Court held that members of the jury would have been sure, in reaching their verdict, that the explanation given at the trial was a late fabrication, satisfying themselves that the real reason for the silence was the lack of an innocent explanation. ${ }^{151}$ Thus, despite the fact that the trial judge had failed to direct the jury members to draw inferences only where they believed the real reason for the silence was that the accused did not

\footnotetext{
${ }^{143}$ Ibid [32].

${ }^{144}$ Ibid [34]; United Kingdom, Crown Court Bench Book: Directing the Jury (United Kingdom, Judicial Studies Board, 2010) [15-414/432].

${ }^{145} R$ v Boyle [2006] EWCA Crim 2101 (25 August 2006) [34].

${ }^{146}$ Condron v United Kingdom (European Court of Human Rights, Chamber, Application No 35718/97, 2 May 2000).

${ }^{147} R v$ Boyle [2006] EWCA Crim 2101 (25 August 2006) [14].

148 Ibid.

${ }^{149}$ Ibid [44].

${ }^{150}$ Ibid.

${ }^{151}$ Ibid [43].
} 
have an answer which would stand up to scrutiny, ${ }^{152}$ the Court found that the jury members nevertheless had that belief when reaching their verdict. Consequently, the Court did not doubt the safety of the convictions and dismissed the appeal. ${ }^{153}$

Boyle ${ }^{154}$ highlights the fact that the test in relation to whether a misdirection will make a conviction unsafe is quite complex. Unlike a simple absolute approach - that all misdirections in relation to section 34 will be miscarriage of justice - the test requires the appeal court to uphold a conviction only where the court is almost certain that the jury would have reached the same decision despite the misdirection. The complexity arises as the appeal court cannot definitively know what impact the impugned aspects of the misdirection actually had on the decision of the jury members, what weight they gave to the section 34 inferences, and whether they would have reached the same decision on the basis of the remaining evidence. ${ }^{155}$ Thus, in determining whether the jury was 'bound to convict' despite the misdirection, the appeal court must place itself in the position of the jury to determine what effect the misdirection would have had and whether the verdict would have been the same, irrespective of the misdirection. It has been argued that this approach, of the appeal court standing in the position of the jury, may prejudice the fairness of the trial, as it usurps the role of the jury. ${ }^{156}$ Further, although in Boyle the misdirection tended to be in favour of the accused, ${ }^{157}$ this will not always be the case.

It is likely that a similar approach will be taken to misdirections in New South Wales. This is primarily due to the existence of the right to a fair trial in both jurisdictions. United Kingdom courts are bound by the European Convention on Human Rights ${ }^{158}$ which includes the right to a fair hearing. ${ }^{159}$ Because of that Convention, the European Court of Human Rights has encouraged United Kingdom appeal courts to deal strictly with cases involving misdirections in

\footnotetext{
${ }^{152}$ United Kingdom, Crown Court Bench Book: Directing the Jury (United Kingdom, Judicial Studies Board, 2010) [15-414/432]

${ }^{153} R v$ Boyle [2006] EWCA Crim 2101 (25 August 2006) [44].

${ }^{154} R v$ Boyle [2006] EWCA Crim 2101 (25 August 2006).

${ }^{155}$ Condron v United Kingdom (European Court of Human Rights, Chamber, Application No 35718/97, 2 May 2000) [63].

${ }^{156}$ Ibid; $R$ v Boyle [2006] EWCA Crim 2101 (25 August 2006) [5].

${ }^{157} R v$ Boyle [2006] EWCA Crim 2101 (25 August 2006) [44].

158 Convention for the Protection of Human Rights and Fundamental Freedoms, opened for signature 4 November 1950, 213 UNTS 222 (entered into force 3 September 1953), ('European Convention on Human Rights').

${ }^{159}$ Ibid art 6.
} 
relation to section $34 .{ }^{160}$ They have also expressly stated that a fair trial cannot be secured by appeal proceedings. ${ }^{161}$ This is because an appeal court is 'in no position to assess properly whether the jury considered [the weight of evidence] to be conclusive of th[e] guilt ${ }^{\prime 162}$ of the accused. In other words, despite the strength of the evidence against the accused, an appeal court cannot know for sure that a jury would reach the same verdict. Thus, a determination that a jury was 'bound to convict', does not afford the accused a fair hearing and should be avoided. Contrary to this recommendation, the court in Boyle refused to take an absolutist approach that all misdirections will require a re-trial, instead looking behind the jury verdict. ${ }^{163}$ While Australian courts, like those of the UK, uphold a common law right to a fair trial, ${ }^{164}$ this right is arguably narrower than that recognised by international conventions. ${ }^{165}$ Although Australia has ratified the International Convenant on Civil and Political Rights, ${ }^{166}$ this country does not have domestic legislation which expressly upholds the right to a fair trial and, although the existence of such a right is well recognised, neither Australian legislation nor its common law contains an exhaustive or comprehensive definition of a 'fair trial' ${ }^{167}$ Therefore, it will arguably be even less likely that a simple absolutist approach to misdirections will be adopted in New South Wales.

Further, Australian courts already apply a non-absolutist approach to misdirections. In the High Court decision of Mule $v R,{ }^{168}$ the defendants argued that the trial judge had erroneously instructed the jury to give less weight to some statements made by the accused to police than others. The High Court held, taking the directions as a whole, that the jury had not been left with an erroneous impression of the applicable law. However, even if there had been a misdirection, whether that misdirection amounted to a miscarriage of justice was 'another matter'. The Court stated that the safety of a conviction will

\footnotetext{
${ }^{160}$ Condron v United Kingdom (European Court of Human Rights, Chamber, Application No 35718/97, 2 May 2000).

${ }^{161}$ Ibid [63].

162 Condron v United Kingdom (European Court of Human Rights, Chamber, Application No 35718/97, 2 May 2000) [63].

${ }^{163} R v$ Boyle [2006] EWCA Crim 2101 (25 August 2006).

${ }^{164}$ Dietrich $v$ The Queen (1992) 177 CLR 292.

${ }^{165}$ D Harris, 'The Rights to a Fair Trial in Criminal Proceedings as a Human Right' (1967) 16 International and Comparative Law Quarterly 352; Sally Kift, 'The Dietrich Dilemma' (1997) 13 Queensland University of Technology Law Journal 211, 211.

${ }^{166}$ International Covenant on Civil and Political Rights, opened for signature 16 December 1966, [1980] ATS 23, (entered into force 13 November 1980) art 14.

${ }^{167}$ Dietrich v R (1992) 177 CLR 292, 300 (Mason CJ and McHugh J), 353 (Toohey J).

168 Mule v R (2005) 221 ALR 85.
} 
instead depend upon whether a 'jury, acting reasonably' was left with an erroneous impression of the law, due to the misdirection. ${ }^{169}$ Like the United Kingdom approach, this approach looks behind the jury verdict to determine the impact of the misdirection on the jury's decision. Again, the appeal court cannot know what impression the jury members actually had or whether they would have reached the same verdict without the misdirection. Given that this test is already applied with respect to misdirections, it is likely that a similar approach will be extended to the new section 89A. However, unlike the previous straightforward direction in relation to evidence of silence, the new section 89A direction is lengthy and complex, making it difficult to determine what impact the misdirection may have had on the verdict. Thus, it is likely that section 89A will introduce the same uncertainties as the United Kingdom direction.

\section{B When Is the Section Triggered? Positive Defence}

Apart from the judicial direction itself, there is also uncertainty in the United Kingdom about whether section 34 will apply at all. One of the areas of controversy is whether or not the accused has mounted a positive defence at trial. The inference under section 34 will not arise simply as a result of the accused person's silence. Rather, the accused person must have failed to mention a fact which was later 'relied on in his defence' 170 in the proceedings. (The same requirement is evident in section 89A.) ${ }^{171}$ This means that the accused must raise facts or evidence as a positive defence for section 34 to apply. While this is generally a straightforward matter, in some cases it can be difficult to determine whether the accused had raised a positive defence in the proceedings. ${ }^{172}$

Although this issue has been raised in a number of cases, Smith ${ }^{173}$ demonstrates the difficulty clearly. In that case, Smith and the co-accused, Burgess, were charged with attempted robbery. The prosecution alleged that Burgess approached the victim and, after asking the victim for money, punched the victim in the face. The prosecution also alleged that Smith had assisted by standing between the victim and his escape route and by threatening to beat the

\footnotetext{
${ }^{169}$ Ibid [24]-[25].

${ }^{170}$ Criminal Justice and Public Order Act 1994 (UK) s 34(1)(a).

${ }^{171}$ Evidence Act 1995 (NSW) s 89A(1)(b).

${ }^{172}$ Davis $v R$ [2010] EWCA Crim 708 (31 March 2010); $R$ v Smith [2011] EWCA Crim 1098 (5 April 2011); $R v$ Chivers [2011] EWCA Crim 1212 (12 April 2011); $R v$ Hackett [2011] 2 Cr App R 3; $R$ v Moshaid [1998] Crim L R 420.

${ }^{173} R v$ Smith [2011] EWCA Crim 1098 (5 April 2011).
} 
victim. Smith, acting on legal advice, gave a 'no comment' interview. ${ }^{174}$ At trial, Smith gave evidence that he was a mere bystander and did not threaten the victim. He also supported the narrative of Burgess, stating that Burgess had asked for a cigarette and not money. The trial judge gave a section 34 direction, stating that Smith's evidence that he had been present but had played no part in the offence could give rise to a section 34 inference.

Smith appealed the decision on the basis that a section 34 direction should not have been given. The appeal court found that the direction was erroneous and allowed the appeal ${ }^{175}$ on the basis that the facts identified by the trial judge as giving rise to the adverse inferences were incorrect. ${ }^{176} \mathrm{In}$ particular, the fact that the accused was present was an agreed fact and therefore could not give rise to any adverse inference, as there could be no suggestion that that fact was a late fabrication. ${ }^{177}$ Further, Smith's bare denial of participation in the offence could not give rise to adverse inferences, as this was not a positive defence. ${ }^{178}$ The appeal court's reasoning was that, if a bare denial, first made at trial, could give rise to an adverse inference, then there would be "no practical difference" 179 between this and treating silence alone as evidence of guilt. It would, contrary to the purpose of the section, ${ }^{180}$ allow inferences against the accused based simply on the fact that he had not denied the allegations when interviewed, rather than because of a risk that the denial was a late fabrication.

The prosecution also argued that Smith's evidence, positively supporting Burgess' version of events, amounted to a positive defence. ${ }^{181}$ The prosecution submitted that this could lead to an inference that there had been a late fabrication between the two accused. Such an inference invoked the application of section 34. ${ }^{182}$ However, the appeal court rejected this argument on three grounds. First, Smith had not been asked about what Burgess had said to the victim in the police interview. Second, the suggestion that Smith's evidence that Burgess had asked for a cigarette was a late concoction had not been put to Smith, and, finally, the trial judge had not specifically referred to that evidence

\footnotetext{
${ }^{174}$ Ibid [2].

175 Ibid [14].

${ }^{176}$ Ibid [14]-[15].

${ }^{177} R v$ Chivers [2011] EWCA Crim 1212 (12 April 2011) [16].

${ }^{178} R v$ Smith [2011] EWCA Crim 1098 (5 April 2011) [17], [19].

${ }^{179}$ Ibid [17]; $R$ v Chivers [2011] EWCA Crim 1212 (12 April 2011) [42].

${ }^{180} R v$ Chivers [2011] EWCA Crim 1212 (12 April 2011) [17], [42]; Brizzalari $v R$ [2004] EWCA Crim 310 (19 February 2004) [57].

${ }^{181} R v$ Smith [2011] EWCA Crim 1098 (5 April 2011) [18].

182 Ibid.
} 
as giving rise to the section 34 direction. ${ }^{183}$ Therefore, the judge should have directed the jury members that they should not draw any adverse inferences from Smith's silence. ${ }^{184}$

Smith highlights one of the key principles of section 34: that an accused must mount a positive defence before adverse inferences can be drawn. It is clear that such a principle will not always be straightforward. In Smith, although the accused did not disclose the fact that he had been present as a mere bystander until his trial, this failure of disclosure could not be held against him. ${ }^{185}$ However, a reasonable jury may nevertheless have expected him to mention that information when interviewed. This makes it difficult for the trial judge to determine whether or not section 34 will apply. It is not simply a question of whether a fact is first raised at trial, but whether the accused had failed to mention that fact because it was a later fabrication. ${ }^{186}$ Thus the trial judge must hypothesise as to the reason why the fact was withheld. This difficulty could lead to greater confusion and uncertainty in other factual scenarios where it is less clear that the accused is making a bare denial. ${ }^{187}$

The new legislation in New South Wales is likely to introduce the same issues into NSW law. As discussed above, section 89A adopts identical wording in many respects to that of section 34. In particular, the relevant fact must be 'relied upon in [the defendant's] defence' 188 in the proceedings in order for adverse inferences to be drawn. Also, the New South Wales legislation expressly defines 'agreed fact' elsewhere to mean 'a fact that the parties to a proceeding have agreed is not ... to be disputed'. ${ }^{189}$ This is analogous with the United Kingdom interpretation, that an agreed fact is a matter which is 'agreed to be true'. ${ }^{190}$ Therefore, in all relevant respects, both jurisdictions interpret the definition of 'agreed fact' in the same manner. Finally, Special Bulletin 31 expressly refers to the United Kingdom case law for guidance on this issue. ${ }^{191}$ Therefore, given the identical wording and interpretation of the term 'agreed

\footnotetext{
${ }^{183}$ Ibid [19].

${ }^{184}$ Ibid [20].

${ }^{185}$ Ibid [16]; $R v$ Chivers [2011] EWCA Crim 1212 (12 April 2011) [45].

${ }^{186} R v$ Chivers [2011] EWCA Crim 1212 (12 April 2011) [17], [42]; Brizzalari $v R$ [2004] EWCA Crim 310 (19 February 2004) [57].

${ }^{187} R v$ Hackett [2011] EWCA Crim 380 (1 March 2011) [17]; $R v$ Chivers [2011] EWCA Crim

1212 (12 April 2011); $R$ v Essa [2009] EWCA Crim 43 (14 January 2009).

${ }^{188}$ Evidence Act 1995 (NSW) s 89A(1)(b).

${ }^{189}$ Ibid s 191.

${ }^{190} R v$ Webber [2004] 1 WLR 404, [28].

${ }^{191}$ Judicial Commission of New South Wales, above n 137.
} 
fact', it is likely that the same principles will apply to and the same confusion be caused by section $89 \mathrm{~A}$.

However, even greater complexity may arise in New South Wales because there is no equivalent to section 35. That provision allows United Kingdom courts to draw adverse inferences from the accused's failure to give oral evidence at the trial. ${ }^{192}$ Therefore, in the United Kingdom, the accused cannot avoid adverse inferences simply by not giving evidence. ${ }^{193}$ However in New South Wales, where there is no such provision, a defendant could potentially avoid unfavourable inferences by giving no evidence at trial and thus not relying on facts which he or she had failed to mention earlier. ${ }^{194}$ This scenario will be governed by section 20 of the Evidence Act 1995 (NSW), which allows a judge to 'comment on a failure of the defendant to give evidence', but provides that the 'comment' must not suggest that the failure to give evidence was because the defendant was, or believed he or she was, guilty of the offence. However, due to the imprecise wording of section 20, particularly the vagueness of the term 'comment on', the common law may nevertheless apply. The common law would allow inferences of guilt to be drawn from silence only where the relevant facts are peculiarly within the accused's knowledge and call for some explanation. ${ }^{195}$ Nevertheless, New South Wales courts may be faced with further issues where accused persons choose not to give evidence at trial, because section 89A will not apply, even where there was non-disclosure by the defendant, unless the defendant relies on a fact in the proceedings. This highlights a possible oversight in the section.

\section{What Constitutes a 'Fact Relied Upon'?}

The fact that the defence mounted by the accused must rely upon 'facts' also causes debate and renders the application of section 34 complex. ${ }^{196}$ The court must distinguish between facts and the mere testing or probing of the prosecution case. Initially, United Kingdom courts restricted the term 'fact' to evidentiary facts. ${ }^{197}$ Therefore section 34 was invoked only where actual evidence was relied upon by the defence and not where speculations,

\footnotetext{
192 Criminal Justice and Public Order Act 1994 (UK) s 35.

${ }^{193} R$ v Moshaid [1998] Crim L R 420.

194 This practice would also avoid the application of Criminal Procedure Act 1986 (NSW) s 146A, as inserted by Criminal Procedure Amendment (Mandatory Pre-trial Defence Disclosure) Act 2013 (NSW).

${ }^{195}$ Evidence Act 1995 (NSW) s 89A(7); Weissensteiner v The Queen (1993) 178 CLR 217, [51][53].

196 Criminal Justice and Public Order Act 1994 (UK) s 34(1).

${ }^{197} R v$ Nickolson [1999] Crim LR 61; $R v$ Webber [2004] 1 WLR 404, [22].
} 
suggestions or possible explanations had been put from the bar table in crossexamination. ${ }^{198}$ However, more recent authorities have given the term 'fact' a broad rather than a 'narrow or pedantic meaning'. ${ }^{199}$ This has led to confusion about what is considered a 'fact' for the purposes of section 34 .

The decision of Webber $^{200}$ highlights this issue. ${ }^{201}$ The question on appeal in that case was whether a suggestion put to a prosecution witness was a 'fact' which invoked section 34. In Webber the appellant had been charged with conspiracy to murder in relation to an alleged drive-by shooting. When questioned by police, Webber simply denied that he had been present. At the trial, the prosecution called both the victim and the victim's associate, who had both been present at the alleged shooting. Counsel for Webber put to the victim and the victim's associate a version of events. He suggested that the victim's associate had actually planned to ambush Webber, and that it had in fact been the victim and his associate who had first fired shots at the car, which had then driven away with Webber firing a single shot into the air. Both witnesses denied this version of events. Webber did not give oral evidence at the trial. The trial judge gave a section 34 direction. He stated that the jury could draw adverse inferences if they believed that the accused could reasonably have been expected to mention to police the version of events put to the witnesses. ${ }^{202}$

On appeal, it was argued that only evidentiary facts could trigger the application of section 34. Webber submitted that suggestions put to a witness were not evidence unless accepted by that witness, and therefore that the section 34 direction should not have been given. ${ }^{203}$ However, the House of Lords was of the opinion that the term 'fact' should instead be given a broad meaning. ${ }^{204}$ It held that, if an accused or their counsel raised a fact, explanation or account, which, if it were true, the accused could have been expected to disclose earlier, then this would be a fact relied upon for the purposes of section $34 .{ }^{205}$ Therefore, because counsel had put a 'specific and positive'206 case to the

\footnotetext{
${ }^{198} R v$ Webber [2004] 1 WLR 404, [22].

${ }^{199}$ Ibid [33].

${ }^{200} R v$ Webber [2004] 1 WLR 404.

${ }^{201}$ Note that the decision of $R v$ Webber is referred to in the Special Bulletin 31 to the New South Wales Trial Court Bench Books. See Judicial Commission of New South Wales, above n 137. also applies where the possible explanation was given by the defendant himself during crossexamination.

${ }^{206} R v$ Webber [2004] 1 WLR 404 [34].
} 
prosecution witnesses, he had gone beyond merely probing or testing. ${ }^{207}$ It was therefore open to the jury members to draw adverse inferences if they were satisfied that the accused could reasonably have been expected to mention the explanation earlier.

The logic of this reasoning is questionable. The implication is that, even if a suggestion is not accepted by the witness, and therefore does not become evidence or provide any evidentiary value to the accused, it may still invoke the application of section $34 .^{208}$ The test relies upon a very fine distinction between facts and hypotheses. ${ }^{209}$ In Webber, because a sufficiently specific and positive suggestion was made, it was considered a fact relied upon. ${ }^{210}$ However, in other decisions the distinction is not as clear. ${ }^{211}$ Problems may arise, particularly in relation to purely circumstantial cases. ${ }^{212}$ In such cases the accused often raise reasonable doubt by offering, within ethical limits, possible innocent explanations for the evidence. The decision in Webber could potentially undermine this practice, affecting the evidentiary burden of proof. The rule that 'fact' is no longer restricted to evidentiary facts may also impose an expectation on accused persons that they will disclose possible theoretical explanations when they are first questioned by police. This will force courts, and juries, to consider the difficult question of whether it was reasonable in the circumstances to expect the defendant to disclose such 'facts' when questioned. ${ }^{213}$

The broader definition of 'facts' similarly creates issues for legal representatives. As the court acknowledged in Webber, although counsel must mount the best possible defence for their client, they will be inhibited by the concern that any suggestion put to a witness could invoke section $34 .^{214}$ The House of Lords indicated that counsel may still test the prosecution case by hypotheses; however counsel must ensure that it is clear that the facts put to the witness are mere suggestions and are not facts relied upon. ${ }^{215}$ Further, the House of Lords cautioned that legal representatives might only advance a positive defence on clear instructions from their client. ${ }^{216}$ Therefore counsel must ensure that their client fully understands the complex operation of section 34 , so that

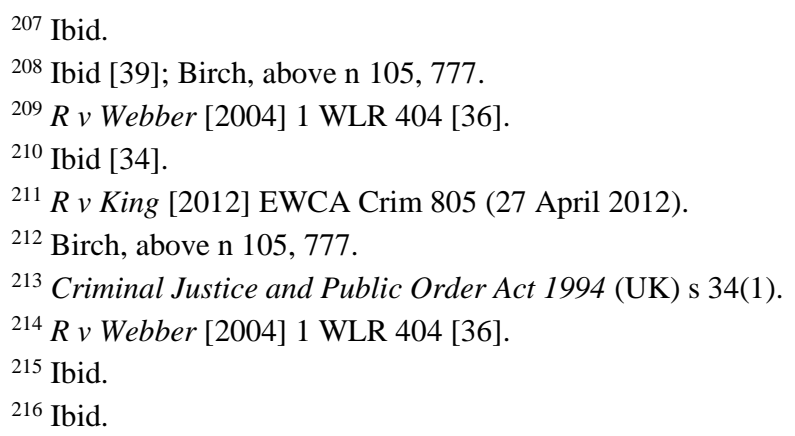


the client can provide informed instructions. This will likely create problems for legal practitioners.

Given the similarity of the wording of section 89A to the United Kingdom provision, there is no reason to believe that the New South Wales legislation will be able to avoid these complexities. Both sections refer to a failure to mention 'facts' later relied upon at trial. ${ }^{217}$ Further, there is nothing in either piece of legislation to expressly define the term 'fact'. ${ }^{218}$ Therefore, given that the United Kingdom case law is likely to be persuasive, ${ }^{219}$ particularly as Webber is expressly referred to in the New South Wales Bench Book, ${ }^{220}$ it appears that similar principles will apply in relation to section 89A. Thus, the new provision will cause the same difficulties in the interpretation of the term 'fact' as are experienced in the United Kingdom.

\section{When Will It Be 'Reasonable' to Remain Silent?}

Due to the uncertainty surrounding section 34, legal practitioners have sought to avoid the application of this provision altogether. One method of avoiding section 34 is to argue for the 'reasonable explanation'. Under the United Kingdom provision, adverse inferences may be drawn only where the accused 'could reasonably have been expected to mention' ${ }^{221}$ the fact which is later relied upon. Therefore, where the accused has a reasonable explanation for not disclosing the relevant fact, no inferences may be drawn. ${ }^{222}$ Again, the same requirement is evident in section $89 \mathrm{~A} .{ }^{223}$ It is arguably unreasonable to expect an accused person to mention certain facts when he or she has not received full disclosure from police, ${ }^{224}$ is unfamiliar with the legal system, ${ }^{225}$ has received

\footnotetext{
${ }^{217}$ Evidence Act 1995 (NSW) s 89A(1); Criminal Justice and Public Order Act 1994 (UK) s 34(1).

${ }^{218}$ Evidence Act 1995 (NSW); Criminal Justice and Public Order Act 1994 (UK).

219 Catriona Cook et al, Laying Down the Law (LexisNexis Butterworths, $7^{\text {th }}$ ed, 2009) [5.25]; Esso Australia Resources Ltd v Federal Commissioner of Taxation (1999) 201 CLR 49, 85.

${ }^{220}$ Judicial Commission of New South Wales, Special Bulletin 31 - Right to silence -the effect of $s$ 89A of the Evidence Act 1995, (August 2013) <http://www.judcom.nsw.gov.au/ publications/benchbks/criminal/special_bulletin_31.html>.

${ }^{221}$ Criminal Justice and Public Order Act 1994 (UK) s 34(1).

${ }^{222}$ Howell v R [2003] EWCA Crim 1 (17 January 2003) [24].

${ }^{223}$ Evidence Act 1995 (NSW) s 89A(1)(a).

${ }^{224}$ Howell $v R$ [2003] EWCA Crim 1 (17 January 2003); $R$ v Betts [2001] 2 Cr App R 16; Argent $v R$ [1997] Crim LR 449.

${ }^{225} R v$ Bresa [2005] EWCA Crim 1414 (26 May 2005).
} 
legal advice, ${ }^{226}$ or believes that he or she is being unlawfully detained. ${ }^{227}$ The question of reasonableness will generally be left to the jury, unless the judge is satisfied that in the circumstances no reasonable jury could find that adverse inferences were appropriate. ${ }^{228}$ However, the content of the judicial direction about this issue has produced significant uncertainty.

One of the most highly litigated issues in this area is the reliance on legal advice. ${ }^{229}$ When an accused person is advised by his solicitor to remain silent, the question arises of whether this was reasonable in the circumstances. The law on this issue in the United Kingdom remains unsettled and complex. While one line of authority suggests that it is the 'genuineness' of the defendant's reliance on the legal advice which is relevant, ${ }^{230}$ the other identifies the relevant question as whether it is objectively reasonable in all of the circumstances to have relied on the advice. ${ }^{231}$

The issue was discussed at length in the decision of Hoare. ${ }^{232}$ In that case two defendants had been charged with producing and conspiring to supply prohibited drugs. The facts involved a large-scale manufacture of amphetamines by Hoare, and the supply of that drug by both Hoare and Pierce. The accused were arrested when Hoare delivered a box containing amphetamines to Pierce. Pierce, who is most relevant for this discussion, was accompanied by his solicitor when interviewed by police. At the start of the interview, Pierce's solicitor stated that he believed that his client was being unlawfully detained and had therefore advised his client not to answer police questions. Pierce then answered 'no comment' to all questions, except to state that he did not know what was in the box. ${ }^{233}$ At the trial Pierce gave oral evidence, stating that the delivery was the first he had received from Hoare and that he believed that it contained glassware. Pierce, in cross-examination, stated that he gave a 'no comment' interview on the basis of legal advice. Pierce's solicitor also gave oral evidence outlining his advice. The prosecution then

\footnotetext{
${ }^{226} R v$ Bresa [2005] EWCA Crim 1414 (26 May 2005); Howell $v R$ [2003] EWCA Crim 1 (17 January 2003); Beckles $v$ United Kingdom [2002] I Eur Court HR 661; $R$ v Bowden [1999] 4 All ER 43; Seaton $v R$ [2011] WLR 623; $R$ v Essa [2009] EWCA Crim 43 (14 January 2009).

${ }^{227} R v$ Hoare and Pierce [2005] 1 WLR 1804.

${ }^{228} R v$ McGarry (1998) 3 All ER 805.

${ }^{229} R v$ Bresa [2005] EWCA Crim 1414 (26 May 2005); Howell $v R$ [2003] EWCA Crim 1 (17 January 2003); Beckles $v$ United Kingdom [2002] I Eur Court HR 661; $R$ v Bowden [1999] 4 All ER 43; Seaton v R [2011] WLR 623; $R$ v Essa [2009] EWCA Crim 43 (14 January 2009). ${ }^{230} R v$ Betts [2001] 2 Cr App R 16; $R$ v Robinson [2003] EWCA Crim 2219 (29 July 2003).

${ }^{231}$ Howell v $R$ [2003] EWCA Crim 1 (17 January 2003); $R$ v Hoare [2005] 1 WLR 1804 [52], [55].

${ }^{232} R v$ Hoare and Pierce [2005] 1 WLR 1804.

${ }^{233}$ Ibid [15].
} 
sought to adduce evidence of the 'no comment' interview. Counsel for Pierce objected on the ground that the evidence had been obtained during a period of unlawful detention. ${ }^{234}$ However, the judge found that the detention was not unlawful and the evidence was adduced. The trial judge then gave a section 34 direction.

One of the grounds of appeal was that the trial judge had misdirected the jury in relation to section 34. In particular, Pierce argued that the trial judge had erroneously directed the jury to apply an objective test of reasonableness rather than the subjective 'genuineness' test in relation to his reliance on legal advice and to take into consideration the explanation for the legal advice. ${ }^{235}$ The Court of Appeal rejected this ground. The Court was of the opinion that there was "no inconsistency' ${ }^{236}$ between the approaches taken by trial judges in relation to the reasonableness of relying on legal advice, despite the perceived disagreement between the earlier judgments. ${ }^{237}$ Auld LJ, delivering the judgment of the Court, held that the real issue was not genuineness or objective reasonableness, but whether or not the legal advice was the true reason for not mentioning the facts later relied upon. ${ }^{238}$ Thus, inferences may only be drawn where the real reason for the silence was that the accused had 'no or no satisfactory explanation' to give. ${ }^{239}$ It is not a question of whether the accused were entitled, or believed they were entitled, not to answer questions, but of whether they relied on the legal advice as a shield. ${ }^{240}$

The appeal court also held that the jury was entitled to consider the explanation given for the legal advice when determining whether it was reasonable for the accused to remain silent. ${ }^{241}$ This seems to conflict with the test itself, as the court considered it immaterial whether or not the accused had, or believed that he had, a good legal basis for not answering questions. ${ }^{242}$ Further, where accused seek to rely on the explanation for legal advice to justify their silence, an issue of waiver of legal professional privilege may arise. ${ }^{243}$ Nevertheless the test is relatively complex to understand and apply, particularly for a lay jury. It

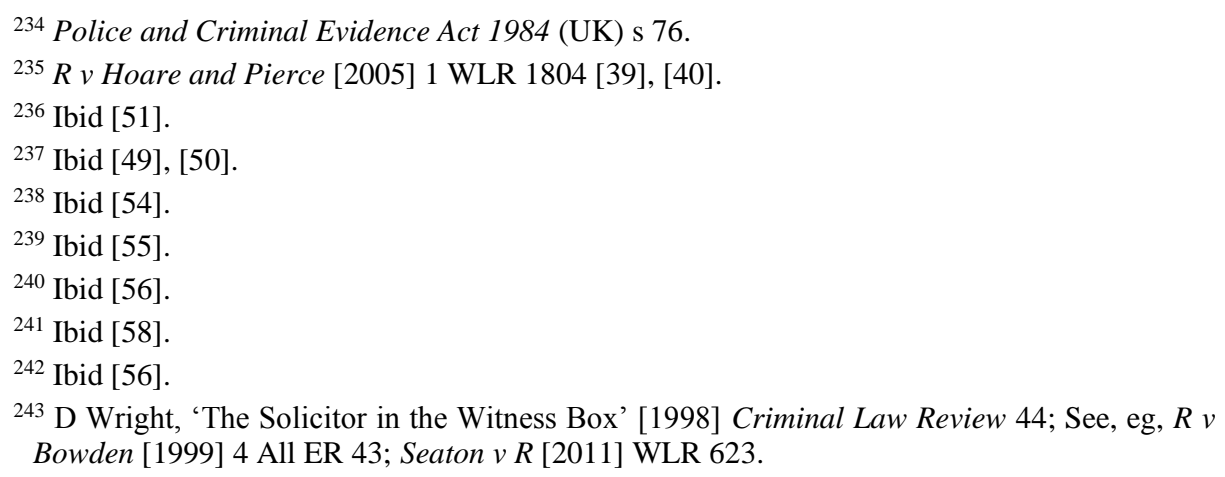


requires the jury to go behind the accused person's explanation for their silence and to determine the real reason that the accused relied on the legal advice.

Given the similarity between section 34 and section $89 \mathrm{~A}$, it is likely that the same complexities will be introduced into the application of the legislation in New South Wales. In particular, both provisions use identical wording to ensure that the inferences may be drawn only where the accused, in the circumstances, 'could reasonably have been expected to have mentioned' the facts later relied upon. ${ }^{244}$ Further, as mentioned above, the Bench Book expressly refers to the United Kingdom authorities as relevant to the interpretation of the new section in New South Wales. ${ }^{245}$ Therefore it is likely that the 'reasonable explanation' element of section $89 \mathrm{~A}$ will operate in the same manner as it does in relation to section 34 .

However, unlike the United Kingdom provision, which simply requires that the defendant had an opportunity to consult with a solicitor, ${ }^{246}$ section 89 A requires an Australian legal practitioner acting for the accused to be present when the special caution is being given. ${ }^{247}$ Although 'presence' is not expressly defined by the legislation, Greg Smith, in the Second Reading Speech to the new legislation, indicated that this is intended to mean the physical presence of a legal practitioner. ${ }^{248}$ This requirement has already created another complexity in that it has become common practice for solicitors, in the interests of their client, to avoid attending the police interview when their client is charged with a serious criminal offence. ${ }^{249}$ The legislators did foresee this loophole in the legislation, referring to it as the 'choice' of the accused. ${ }^{250}$ However, it is evident that this requirement has rendered 89A inapplicable in many cases, as

\footnotetext{
${ }^{244}$ Evidence Act 1995 (NSW) s 89A(1)(a); Criminal Justice and Public Order Act 1994 (UK) s 34(1).

245 Judicial Commission of New South Wales, above $\mathrm{n} 141$.

${ }^{246}$ Criminal Justice and Public Order Act 1994 (UK) s 34(2A).

${ }^{247}$ Evidence Act 1995 (NSW) s 89A(2)(c).

${ }^{248}$ New South Wales, Parliamentary Debates, Legislative Council, 13 March 2013, 87 (Greg Smith).

${ }^{249}$ David Hamer, NSW Right to Silence Reforms (11 February 2013) University of Sydney <http://sydney.edu.au/law/news/docs_pdfs_images/2013/Feb/Hamer_Silence_Semina_Bar_A ssoc11Feb2013.pdf>.

${ }^{250}$ New South Wales, Parliamentary Debates, Legislative Council, 20 March 2013, 2 (Michael Gallacher); New South Wales, Parliamentary Debates, Legislative Council, 13 March 2013, 87 (Greg Smith).
} 
astute counsel may avoid the police station to circumvent the application of section $89 \mathrm{~A}^{251}$

\section{CONCLUSION}

It is apparent from the operation of the equivalent United Kingdom provision that section 89A is likely to introduce significant problems into NSW law. Far from section 89A taking a common sense approach, it rather introduces complexity and uncertainty into the legislation that will make it unworkable. The need for extensive and complicated jury directions, the problems in determining whether the provision is invoked at all, and the complex test of whether it was reasonable for the accused to remain silent, will create significant issues in the application of section 89A. When these issues are balanced against the minimal benefits expected from the new provision, a strong case can be made that the amendment is an unwarranted further intrusion into an already eroded right of accused persons. Further, any purported efficiency that may be achieved through early disclosure will be offset by the substantial inefficiency caused by the problems associated with applying section 89A. Unfortunately, due to the highly political nature of the amendment, it is unlikely that this legislation will be repealed in the short term and any call for its reform would be politically futile. However, in the light of this analysis, which shows that New South Wales courts are likely to encounter significant and ongoing issues, the close monitoring of this legislation is warranted. If the analysis is correct, and the expectation of problems is borne out in the short term, it is hoped that at the very least a thorough review of the legislation will be undertaken with a view to its possible repeal.

\footnotetext{
${ }^{251}$ See, eg, Andrew Clennell, 'Defence Lawyers Exploit Loophole in Right to Silence laws', The Daily Telegraph (online), 15 October 2013 <http://www.dailytelegraph.com.au/news/ nsw/defence-lawyers-exploit-loophole-in-right-to-silence-laws/story-fni0cx12-1226739928 098>.
} 